\title{
The stance of Jehovah's Witnesses on the use blood and Hospital Liaison Committee
}

\author{
Jong Hyun Lee ${ }^{1}$, and Wonsik Ahn ${ }^{2}$ \\ Department of Anesthesiology and Pain and Medicine, ' ${ }^{1}$ Sejong General Hospital, Bucheon, ${ }^{2}$ Seoul National University Hospital, \\ Seoul, Korea
}

Doctors, particularly those in the department of anesthesiology, face unique challenges when treating Jehovah's Witness (JW) patients. Such patients refuse to accept blood transfusions based on their firm religious convictions. Some doctors may think that their hands are tied when patients refuse a blood transfusion. However, it should be noted that even non-JW patients occasionally decide not to follow the doctor's recommendations. According to Appelbaum and Roth [1], 19\% of patients hospitalized at one university hospital refused at least one type of treatment or treatment procedure. Among them, $15 \%$ did so despite the "possibility that their life could be endangered." JWs willingly accept treatments that do not involve blood transfusion, and alternative treatments to blood transfusions are being advanced at a rapid pace [2]. Therefore, an open-minded approach to this issue is certainly possible.

\section{The Stance of JWs on the Use of Blood}

JWs refuse the injection of whole blood, packed red cells, fresh frozen plasma, platelets and white cells. However, there is no blanket ban on the administration of albumin, immunoglobulin or blood clotting factors. JWs believe that blood that has left their body must be discarded, and therefore, prohibit the use of preoperative autologous blood donation. However, according to experience, most JWs accept treatment methods where the blood has left one's body, connected directly to the body in a closed-circuit, and re-infused immediately, such as acute normovolemic hemodilution or cell salvage. Similar principles apply to the use of cardiopulmonary bypass and artificial kidneys. JWs are actively prescribed the pre-operational administration of erythropoietin and iron supplements. Anemia can be avoided in many cases by increasing the blood cell count prior to surgery using such means [3].

The choices of JWs on certain treatment methods can vary. A prior explanation of the treatment method and informed consent of the patient is necessary because the acceptance of treatment methods that are not strictly prohibited is a matter of personal decision, such as albumin or coagulation factors. For this reason, JWs operate a Hospital Liaison Committee to minimize any legal or moral conflicts that may arise between patients and physicians. Having their contact information ahead of time helps to stabilize patients and maintain the focus on medical treatment without delay. The telephone number of the Korean Hospital Liaison Committee of Jehovah's Witnesses representative is 82-31-690-0123, and can be used in emergency situations 24 hours/ 7 days.

\section{References}

1. Appelbaum PS, Roth LH. Patients who refuse treatment in medical hospitals. JAMA 1983; 250: 1296-301.

2. Moskowitz DM, McCullough JN, Shander A, Klein JJ, Bodian CA, Goldweit RS, et al. The impact of blood conservation on outcome in cardiac surgery: is it safe and effective? Ann Thorac Surg 2010; 90: 451-8.

3. Sonzogni V, Crupi G, Poma R, Annechino F, Ferri F, Filisetti P, et al. Erythropoietin therapy and preoperative autologous blood donation in children undergoing open heart surgery. Br J Anaesth 2001; 87: 429-34.

Corresponding author: Jong Hyun Lee, M.D., Department of Anesthesiology and Pain and Medicine, Sejong General Hospital, 91-121, Sosabon 2-dong, Sosa-gu, Bucheon 422-711, Korea. Tel: 82-32-340-1254, Fax: 82-32-349-3005, E-mail: jonghyeonlee@gmail.com

(c) This is an open-access article distributed under the terms of the Creative Commons Attribution Non-Commercial License (http:// creativecommons.org/licenses/by-nc/3.0/), which permits unrestricted non-commercial use, distribution, and reproduction in any medium, provided the original work is properly cited. 